\title{
Parametric optimization of corrosion and wear of electroless Ni-P-Cu coating using grey relational coefficient coupled with weighted principal component analysis
}

\author{
Supriyo Roy and Prasanta Sahoo*
}

\begin{abstract}
Background: This research article considers optimization of the four process parameters based on corrosion and wear of electroless Ni-P-Cu coatings. The major characteristics indexes for performance selected to evaluate the processes are corrosion potential $\left(E_{\text {corr }}\right)$, corrosion current density $\left(I_{\text {corr }}\right)$ and wear. Among the corresponding four process parameters the first three are coating parameters, viz. concentration of nickel sulphate, concentration of sodium hypophosphite, concentration of copper sulphate and the fourth one is post deposition heat treatment temperature.
\end{abstract}

Methods: The corrosion property, i.e. $E_{\text {corr }}$ and $I_{\text {corr }}$ has been studied by potentiodynamic polarization test and the wear is measured in terms of wear depth by DUCOM TR-25 multi-tribotester with block on roller arrangement.

Results: In this study, the process is intrinsically combined with multiple performance indexes so that grey relational analysis is specially adopted to determine the optimal combination of coating parameters. Moreover, the weighted principal component analysis (WPCA) is applied to evaluate the weighting values corresponding to various performance characteristics so that their relative importance can be properly and objectively described.

Conclusion: From the analysis the optimum combination of parameters for corrosion property and the optimum combination of parameters for corrosion and wear together are obtained. The chemical composition, surface morphology and phase behaviour are investigated using energy dispersive $\mathrm{X}$-ray analysis, scanning electron microscopy and X-ray diffraction analysis, respectively.

Keywords: Ni-P-Cu; Corrosion; Wear; Grey relational coefficient; WPCA

\section{Background}

Coating is a method by which an artificial surface can be generated to the outer surface of the substrate material to protect it from corrosion and wear. These are the two deteriorating phenomena which are the source of major loss for industrial machinery. These not only reduce the life of the industrial components but also increase the maintenance cost and expenditure for replacement of parts. Since corrosion and wear both occur at the surface of the substrate, they can be reduced or eliminated by surface treatment. In this respect, the metallic surface

\footnotetext{
* Correspondence: psjume@gmail.com

Department of Mechanical Engineering, Jadavpur University, Kolkata 700032,
} India

coating gives a practical solution. Electroless coating, also known as chemical or auto-catalytic coating, is a non-galvanic plating method that involves several simultaneous chemical reactions in an aqueous solution, which occur without the use of external electrical power. That makes the difference of this process with that of conventional electroplating process which requires external current source. Electroless coating process has gained wide acceptance in the market due to the excellent corrosion and wear resistance properties, and it is also good for soldering and brazing purposes (Sahoo and Das 2011). In recent days the binary electroless Ni-P coatings have become the research focus due to their 
Table 1 Main coating parameters with their levels

\begin{tabular}{llll}
\hline Design factors & Levels & & \\
\cline { 2 - 4 } & $\mathbf{1}$ & $\mathbf{2}$ & $\mathbf{3}$ \\
\hline $\begin{array}{l}\text { Concentration of source of nickel } \\
\text { (nickel sulphate solution) }(\mathrm{g} / \mathrm{l})\end{array}$ & 25 & 30 & 35 \\
$\begin{array}{l}\text { Concentration of reducing agent } \\
\text { (sodium hypophosphite solution) }(\mathrm{g} / \mathrm{l})\end{array}$ & 10 & 15 & 20 \\
$\begin{array}{l}\text { Concentration of source of copper } \\
\text { (copper sulphate) }(\mathrm{g} / \mathrm{l})\end{array}$ & 0.3 & 0.5 & 0.7 \\
\begin{tabular}{l} 
Heat treatment temperature $\left({ }^{\circ} \mathrm{C}\right)$ \\
\hline
\end{tabular} & 300 & 400 & 500 \\
\hline
\end{tabular}

more superior properties. These properties can be further improved by incorporating a third particle into that binary alloy. The choice of the third particle depends on the desired property. Ternary Ni-P coatings, such as $\mathrm{Ni}-\mathrm{Cu}-\mathrm{P}$ (Yu et al. 2002; Aal and Aly 2009), Ni-W-P (Palaniappa and Seshadri 2008; Balaraju et al. 2006a; Balaraju et al. 2006b; Roy and Sahoo 2013; Roy and
Sahoo 2012), Ni-P-TiO 2 (Abdel Aal et al. 2008; Chen et al. 2010; Novakovic and Vassiliou 2009), Ni-P- $\mathrm{Al}_{2} \mathrm{O}_{3}$ (Alirezaei et al. 2007; Balaraju et al. 2006c), Ni-P-PTFE (Ramalho and Miranda 2005; Huang et al. 2003) and $\mathrm{Ni}-\mathrm{P}-\mathrm{SiC}$ (Lin et al. 2006; Jiaqiang et al. 2006), have been prepared by electroless deposition. Among these ternary $\mathrm{Ni}-\mathrm{P}$ alloy coatings, the electroless $\mathrm{Ni}-\mathrm{Cu}-\mathrm{P}$ alloy presents more superior corrosion resistance and thermal conductivity than the others (Liu et al. 2010; Valova et al. 2010; Liu and Zhao 2004; Wang et al. 1992). The inclusion of $\mathrm{Cu}$ in electroless $\mathrm{Ni}-\mathrm{P}$ alloys improves their smoothness (Balaraju and Rajam 2005), brightness (Tarozaitë and Selskis 2006; Chen et al. 2006) and corrosion resistance (Liu and Zhao 2004; Zhao et al. 2004; Armyanov and Georgieva 2007). The crystallization behaviours of $\mathrm{Ni}-\mathrm{P}-\mathrm{Cu}$ coatings on aluminium substrates were investigated by Chen and Lin (1999). A comparative study on the crystallization

Table $2 L_{27}$ orthogonal array

\begin{tabular}{|c|c|c|c|c|c|c|c|c|c|c|c|c|c|}
\hline \multirow{2}{*}{$\begin{array}{l}\text { Trial } \\
\text { number }\end{array}$} & \multicolumn{13}{|c|}{ Column numbers } \\
\hline & $1(A)$ & $2(B)$ & $3(A \times B)$ & $4(A \times B)$ & $5(C)$ & $6(A \times C)$ & $7(A \times C)$ & $8(B \times C)$ & $9(D)$ & 10 & $11(B \times C)$ & 12 & 13 \\
\hline 1 & 1 & 1 & 1 & 1 & 1 & 1 & 1 & 1 & 1 & 1 & 1 & 1 & 1 \\
\hline 2 & 1 & 1 & 1 & 1 & 2 & 2 & 2 & 2 & 2 & 2 & 2 & 2 & 2 \\
\hline 3 & 1 & 1 & 1 & 1 & 3 & 3 & 3 & 3 & 3 & 3 & 3 & 3 & 3 \\
\hline 4 & 1 & 2 & 2 & 2 & 1 & 1 & 1 & 2 & 2 & 2 & 3 & 3 & 3 \\
\hline 5 & 1 & 2 & 2 & 2 & 2 & 2 & 2 & 3 & 3 & 3 & 1 & 1 & 1 \\
\hline 6 & 1 & 2 & 2 & 2 & 3 & 3 & 3 & 1 & 1 & 1 & 2 & 2 & 2 \\
\hline 7 & 1 & 3 & 3 & 3 & 1 & 1 & 1 & 3 & 3 & 3 & 2 & 2 & 2 \\
\hline 8 & 1 & 3 & 3 & 3 & 2 & 2 & 2 & 1 & 1 & 1 & 3 & 3 & 3 \\
\hline 9 & 1 & 3 & 3 & 3 & 3 & 3 & 3 & 2 & 2 & 2 & 1 & 1 & 1 \\
\hline 10 & 2 & 1 & 2 & 3 & 1 & 2 & 3 & 1 & 2 & 3 & 1 & 2 & 3 \\
\hline 11 & 2 & 1 & 2 & 3 & 2 & 3 & 1 & 2 & 3 & 1 & 2 & 3 & 1 \\
\hline 12 & 2 & 1 & 2 & 3 & 3 & 1 & 2 & 3 & 1 & 2 & 3 & 1 & 2 \\
\hline 13 & 2 & 2 & 3 & 1 & 1 & 2 & 3 & 2 & 3 & 1 & 3 & 1 & 2 \\
\hline 14 & 2 & 2 & 3 & 1 & 2 & 3 & 1 & 3 & 1 & 2 & 1 & 2 & 3 \\
\hline 15 & 2 & 2 & 3 & 1 & 3 & 1 & 2 & 1 & 2 & 3 & 2 & 3 & 1 \\
\hline 16 & 2 & 3 & 1 & 2 & 1 & 2 & 3 & 3 & 1 & 2 & 2 & 3 & 1 \\
\hline 17 & 2 & 3 & 1 & 2 & 2 & 3 & 1 & 1 & 2 & 3 & 3 & 1 & 2 \\
\hline 18 & 2 & 3 & 1 & 2 & 3 & 1 & 2 & 2 & 3 & 1 & 1 & 2 & 3 \\
\hline 19 & 3 & 1 & 3 & 2 & 1 & 3 & 2 & 1 & 3 & 2 & 1 & 3 & 2 \\
\hline 20 & 3 & 1 & 3 & 2 & 2 & 1 & 3 & 2 & 1 & 3 & 2 & 1 & 3 \\
\hline 21 & 3 & 1 & 3 & 2 & 3 & 2 & 1 & 3 & 2 & 1 & 3 & 2 & 1 \\
\hline 22 & 3 & 2 & 1 & 3 & 1 & 3 & 2 & 2 & 1 & 3 & 3 & 2 & 1 \\
\hline 23 & 3 & 2 & 1 & 3 & 2 & 1 & 3 & 3 & 2 & 1 & 1 & 3 & 2 \\
\hline 24 & 3 & 2 & 1 & 3 & 3 & 2 & 1 & 1 & 3 & 2 & 2 & 1 & 3 \\
\hline 25 & 3 & 3 & 2 & 1 & 1 & 3 & 2 & 3 & 2 & 1 & 2 & 1 & 3 \\
\hline 26 & 3 & 3 & 2 & 1 & 2 & 1 & 3 & 1 & 3 & 2 & 3 & 2 & 1 \\
\hline 27 & 3 & 3 & 2 & 1 & 3 & 2 & 1 & 2 & 1 & 3 & 1 & 3 & 2 \\
\hline
\end{tabular}


behaviour of electroless $\mathrm{Ni}-\mathrm{P}$ and $\mathrm{Ni}-\mathrm{Cu}-\mathrm{P}$ deposits was performed by Hui-Sheng et al. (2001) and found that the crystalline temperature for the formation of $\mathrm{Ni}_{3} \mathrm{P}$ phase is higher for $\mathrm{Ni}-\mathrm{Cu}-\mathrm{P}$ coating than $\mathrm{Ni}-\mathrm{P}$ coating. It was mentioned that the addition of copper into electroless Ni-P matrix could improve the corrosion resistance of the coatings (Mallory and Hadju 1991). The corrosion study of electroless $\mathrm{Ni}-\mathrm{P}-\mathrm{Cu}$ reveals that $90 \%$ $\mathrm{Ni}-7 \% \mathrm{Cu}-3 \% \mathrm{P}$ in $50 \% \mathrm{NaOH}$ solution was better than that of as-plated Ni-P (Wang et al. 1992). The anticorrosion properties of the Ni-Cu-P coatings in $1 \mathrm{M} \mathrm{HCl}, 1 \mathrm{M}$ $\mathrm{H}_{2} \mathrm{SO}_{4}$ and $3 \% \mathrm{NaCl}$ solutions were investigated by Cissé et al. (2010) using Tafel polarization curves and electrochemical impedance spectroscopy. The result showed a marginal improvement in corrosion resistance in $3 \% \mathrm{NaCl}$ solution compared to acidic medium. As the corrosion and wear property of this coating depends on the coating parameters, the parameters can be optimized for best corrosive media, i.e. $\mathrm{NaCl}$ solution. Practically, both the corrosion and wear take place simultaneously; hence, the parameters can be optimized taking the effect of corrosion and wear together. The Taguchi method is a statistical approach for the purpose of designing and improving product quality. Tosun (2006) used the grey relational analysis for the determination of optimal drilling parameters with the objective of minimization of surface roughness and burr height. Deng (1982) proposed the grey system theory which has been proven to be useful for dealing with the problems with poor, insufficient and uncertain information. The grey-based Taguchi method was employed to optimize the process parameters of the submerged arc welding (SAW) in hardfacing, considering multiple weld qualities (Tarng et al. 2002). Grey relational analysis was adopted to investigate the electro discharge machining (EDM) parameters on machining $\mathrm{Al}-10 \% \mathrm{SiCp}$ composites by Narender Singh et al. (2004). Several researchers have used grey relational method to optimize the design process parameters, but most of the researchers have selected the weighting values of the response parameters according to their own estimation during calculation of the grey relational grade. This method cannot emphasize the relative importance of the response parameters related with the experiment. The case study by Antony (2000) demonstrates the potential of multi-response optimization in industrial experiments using Taguchi's quality loss function and principal component analysis. The research of Lua et al. (2009) about the optimization problem with multiple performance characteristics using grey relational analysis presents a remedy by calculating the corresponding weighting values using principal component analysis (Hotelling 1993). The researchers have used grey relational analysis for optimizing combination of cutting parameters and principal component analysis for determining the corresponding weighting values of various performance
Table 3 Electroless bath constituents

\begin{tabular}{ll}
\hline Parameters & Values \\
\hline Nickel sulphate $(\mathrm{g} / \mathrm{l})$ & 25 to 35 \\
Sodium hypophosphite $(\mathrm{g} / \mathrm{l})$ & 10 to 20 \\
Sodium citrate $(\mathrm{g} / \mathrm{l})$ & 15 \\
Copper sulphate $(\mathrm{g} / \mathrm{l})$ & 0.3 to 0.7 \\
$\mathrm{pH}$ & 9.5 \\
Temperature $\left({ }^{\circ} \mathrm{C}\right)$ & 85 \\
Duration of coating $(\mathrm{h})$ & 2 \\
Bath volume $(\mathrm{ml})$ & 200 \\
\hline
\end{tabular}

characteristics. In this present investigation, the optimum combination of parameters for corrosion and wear, the grey relational coefficient is used and the corresponding weighing value of each performance characteristics calculated by weighted principal component analysis considering the grey relational coefficients and the effect of all responses are clubbed together into multiple performance index. The surface morphology, chemical composition and phase transformation behaviour were studied by scanning electron microscopy (SEM), energy dispersive X-ray spectroscopy (EDX) and X-ray diffraction (XRD) analyses, respectively.

\section{Methods}

\section{Selection of parameters}

The electroless coatings involve large number of process parameters which can affect the performance characteristics of the coatings. In this present study, after a large number of literature review and experimental trials, four main process parameters have been selected as input parameters. Among the four parameters the first three are coating parameters, viz. concentration of nickel sulphate (source of nickel), concentration of sodium hypophosphite (reducing agent) and concentration of copper sulphate (source of copper), and the fourth one is the postdeposition heat treatment temperature. The operating

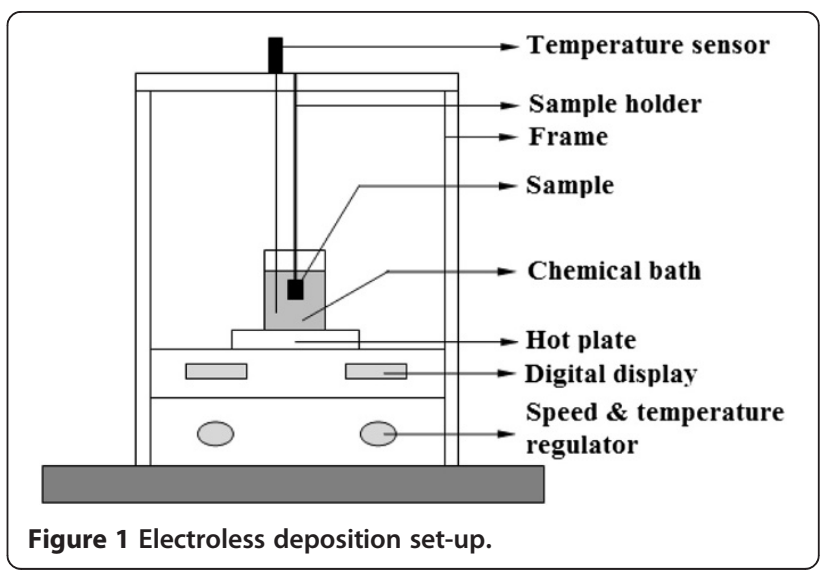




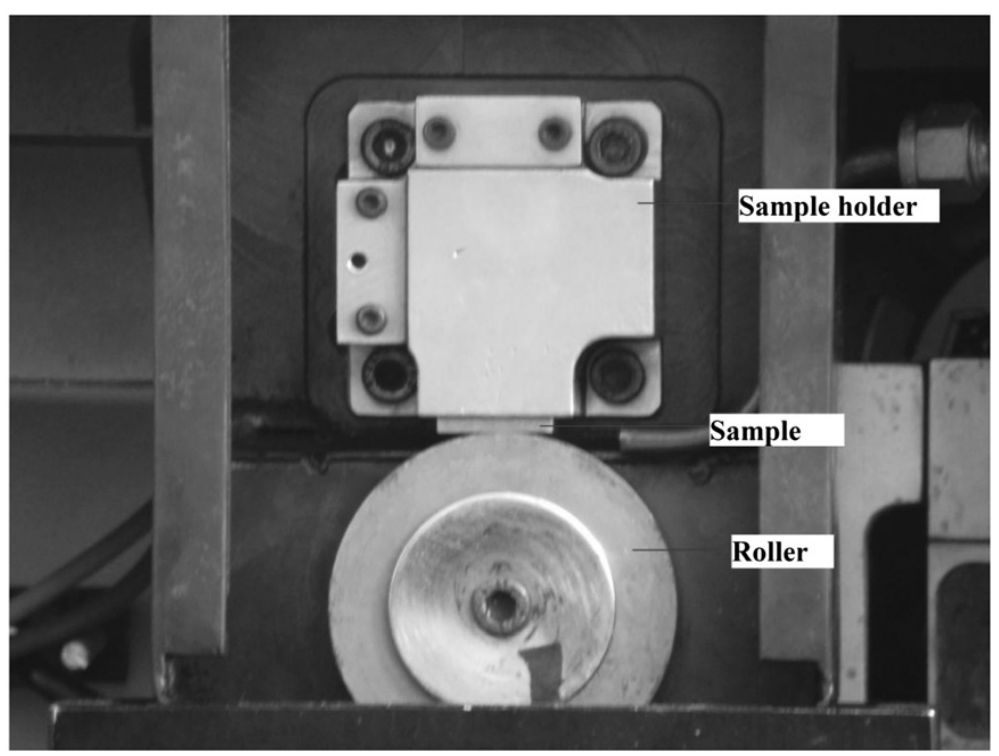

Figure 2 Block on roller arrangement for wear test.

range of the parameters has been selected on the experimental basis, within which the coating can be deposited. The range of each parameter has been divided in to three equally spaced levels. The main parameters with their values are shown in Table 1. The responses are corrosion potential, corrosion current density and wear depth.

\section{Experimental design}

This experimental investigation consists of four threelevel input parameters; hence, with all possible combinations, a total number of $(3)^{4}=81$ experiments can be carried out. To save time and cost, the number of experiments has been reduced by using Taguchi's specially developed orthogonal array (OA). The selection of OA depends on the number of individual parameters and their interaction considered for the analysis. In this study along with four individual parameters, the interactions between three coating parameters, i.e. interaction between nickel sulphate and sodium hypophosphite, sodium hypophosphite and copper sulphate, and nickel sulphate and copper sulphate, have been considered. As this is a three-level experiment, the total degrees of freedom associated with this experiment is 20 . Hence a standard $\mathrm{L}_{27} \mathrm{OA}$ has been selected as this has 26 degrees of freedom which is higher than the degrees of freedom of experiment. A standard $\mathrm{L}_{27} \mathrm{OA}$ is shown in Table 2, which consists of 27 rows and 13 columns. Each row represents the combination of parameters for deposition of coating, and each column indicates the individual factors and their interactions.

\section{Results and discussion \\ Coating deposition}

Mild steel blocks (AISI 1040) of size $20 \mathrm{~mm} \times 20 \mathrm{~mm} \times$ $8 \mathrm{~mm}$ are used as substrates for the deposition of electroless Ni-P-Cu coating. This particular dimension of the sample is chosen to fit the counter part of block on roller multi-tribotester apparatus. The sample is mechanically cleaned from foreign matters and corrosion products. After that, the MS sample is cleaned using distilled water. Then, a pickling treatment is given to the specimen with dilute (50\%) hydrochloric acid for $1 \mathrm{~min}$ to remove any surface layer formed like rust followed by rinsing in distilled water and methanol cleaning. Table 3 indicates the bath composition and the operating conditions for successful coating of electroless Ni-P-Cu.

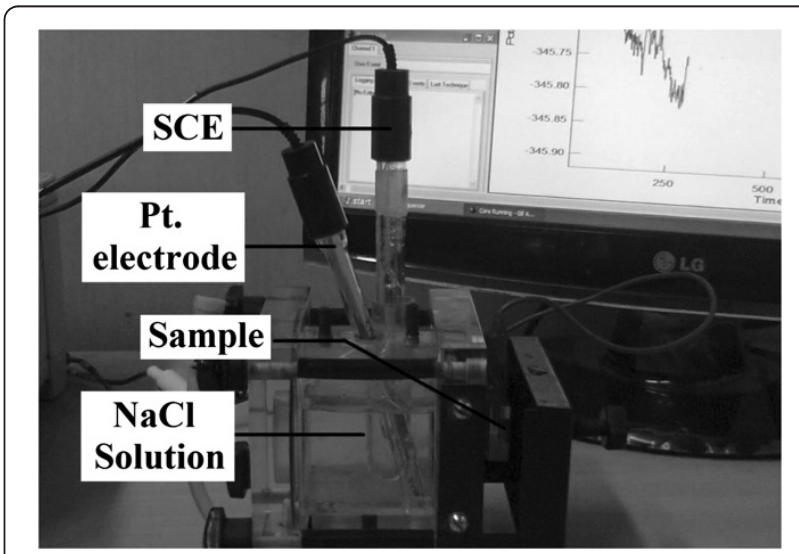

Figure 3 Potentiodynamic polarization test arrangement. 
Nickel sulphate is used as the source of nickel while sodium hypophosphite is the reducing agent and sodium citrate was added as complexing agent. The bath is prepared by adding the constituents in appropriate sequence. The $\mathrm{pH}$ of the solution is maintained around 9.5 by continuous monitoring with a $\mathrm{pH}$ meter. The cleaned samples are activated in palladium chloride solution at a temperature of $55^{\circ} \mathrm{C}$. Activated samples are then submerged into the electroless bath which is maintained at a temperature of $85^{\circ} \mathrm{C}$ with the help of a hot plate cum stirrer attached with a temperature sensor also submerged in the solution. The deposition is carried out for $2 \mathrm{~h}$. The range of coating thickness is found to lie around 28 to $30 \mu \mathrm{m}$ by measuring with a digital micrometer instrument. After deposition, the samples are taken out of the bath and heat-treated according to the experimental design. Figure 1 shows the schematic diagram of coating deposition set-up.

\section{Wear measurement}

The wear depths of heat-treated Ni-P-Cu-coated specimens are measured under non-lubricated condition using a multi-tribotester with block on roller configuration (DUCOM TR-25, Bangalore, Karnataka, India). The Ni-P-Cu-coated specimens serve as test specimens of average hardness of $42 \mathrm{HRc}$, which are held horizontally against a rotating roller coated with titanium nitride of hardness $85 \mathrm{HRc}$ of 50 -mm diameter $\times 20$ - $\mathrm{mm}$ thickness, as shown in Figure 2. As the hardness of the roller is higher than the hardness of coating, it may be assured that the wear will take place on the coating only. The wear test of each specimen is carried out for 5 min with $25 \mathrm{~N}$ load at a speed of $50 \mathrm{rpm}$. Dead weights are placed on the loading platform which is attached at one end of a 1:5 ratio loading lever. A linear voltage resistance transducer is used for measuring wear in terms of wear depth. It is worth noting that, in general, wear is measured in terms of wear volume or mass loss. However, in the present case, wear is expressed in terms of displacement or wear depth. Hence, to ensure that the wear measurements are accurate, the wear depth results are compared with the weight loss of the specimens and almost linear relationship is observed between the two for the range of test parameters considered in the present study.

\section{Polarization study}

The potentiodynamic polarization tests of heat-treated $\mathrm{Ni}-\mathrm{P}-\mathrm{Cu}$ coatings are carried out using a potentiostat (Gill AC) of ACM Instruments, UK, shown in Figure 3. The corrosion parameters were measured by potentiodynamic polarization curve measurements. The tests are conducted at an ambient temperature of about $25^{\circ} \mathrm{C}$ with $3.5 \%$ sodium chloride solution as the electrolyte. The electrochemical cell consists of three electrodes. The coated specimen forms the working electrode which is actually the sample being interrogated. A saturated calomel electrode (SCE) forms the reference electrode which provides a stable 'reference' against which the applied potential may be accurately measured. A platinum electrode serves as the counter electrode which provides the path for the applied current into the solution. The design of the cell kit is such that only an area of $1 \mathrm{~cm}^{2}$ of the coated surface is exposed to the electrolyte. The experimental set-up is shown in Figure 1. A settling time of $15 \mathrm{~min}$ is assigned before every experiment in order to stabilize the open circuit potential (OCP). The potentiostat is controlled via a PC which also captures the polarization data. Potentiodynamic polarization studies were carried out by polarizing the working electrode

Table 4 Results of corrosion and wear test

\begin{tabular}{llll}
\hline Experiment number & $\boldsymbol{E}_{\text {corr }}(\mathrm{mV}$ vs. SCE $)$ & $\boldsymbol{I}_{\text {corr }}\left(\boldsymbol{\mu A} / \mathrm{cm}^{2}\right)$ & Wear $(\mu \mathrm{m})$ \\
\hline 1 & -353.66 & 0.191 & 18.98 \\
2 & -233.31 & 0.7903 & 26.6168 \\
3 & -369.54 & 4.651 & 11.5636 \\
4 & -231.58 & 0.1379 & 10.4644 \\
5 & -304.83 & 0.6771 & 4.3218 \\
6 & -526.89 & 8.627 & 13.0348 \\
7 & -434.42 & 1.104 & 20.4475 \\
8 & -256.26 & 0.7201 & 15.979 \\
9 & -417.6 & 1.264 & 9.3686 \\
10 & -583.88 & 1.7968 & 9.7621 \\
11 & -434.89 & 0.9978 & 13.653 \\
12 & -558.04 & 4.3578 & 18.1084 \\
13 & -346.32 & 2.533 & 14.6986 \\
14 & -443.27 & 0.8437 & 1.432 \\
15 & -458.24 & 5.135 & 18.086 \\
16 & -434.01 & 0.2643 & 25.949 \\
17 & -528.22 & 2.6583 & 25.3954 \\
18 & -461.35 & 5.009 & 14.3488 \\
19 & -576.21 & 5.0188 & 11.369 \\
20 & -601.63 & 3.822 & 1.4966 \\
21 & -437.01 & 8.118 & 25.32 \\
22 & -559.43 & 3.84 & 18.414 \\
23 & -484.94 & 9.864 & 17.4277 \\
24 & -563.11 & 0.77731 & 13.9094 \\
25 & -523.09 & 5.231 & 16.5901 \\
26 & -466.68 & 7.961 & 13.4266 \\
27 & -491.15 & 2.312 & 10.2618 \\
\hline
\end{tabular}


from the OCP to $250 \mathrm{mV}$ in cathodic direction and $250 \mathrm{mV}$ in anodic direction at a scan rate of $1 \mathrm{mV} / \mathrm{s}$. The corrosion current densities $\left(I_{\text {corr }}\right)$ were determined by extrapolating the straight-line section of the anodic and cathodic branches of the Tafel plots in the vicinity of the corrosion potential using the software installed in the instrument The polarization plot is obtained from the dedicated software, which also possesses a special tool in order to manually extrapolate the values of $E_{\text {corr }}$ (corrosion potential) and $I_{\text {corr }}$ (corrosion current density) from the plot. Each experiment has been repeated for three times, and the variation of result was within $2 \%$. The average value has been taken for analysis. The results of wear and corrosion are shown in Table 4. The Tafel plots and the variation of wear are shown in Figure 4

\section{Characterization of coating}

The characterization of the coating is necessary so that it can be made sure that the coating is properly developed. Energy dispersive X-ray analysis (EDAX Corporation, Mahwah, NJ, USA) is performed to determine the
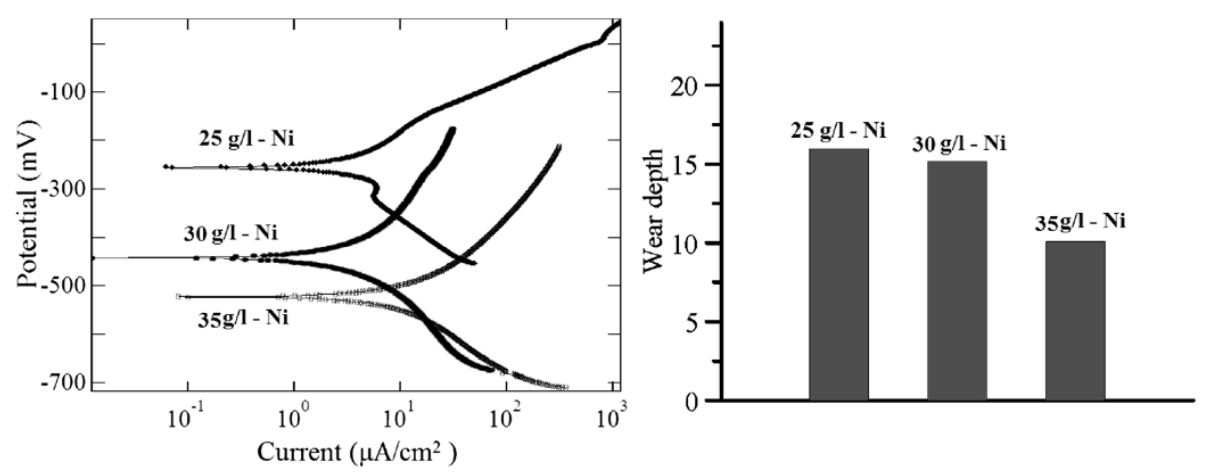

(a)
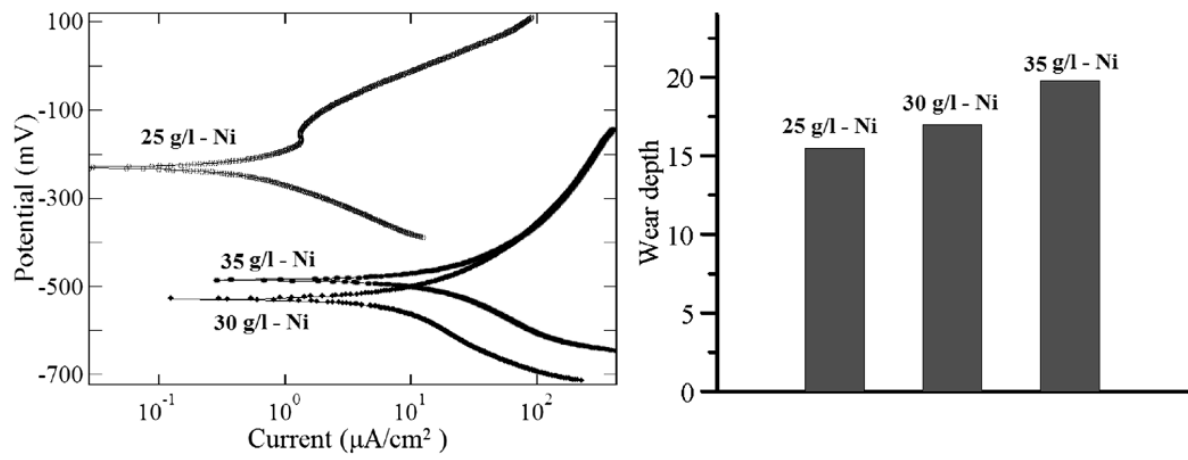

(b)
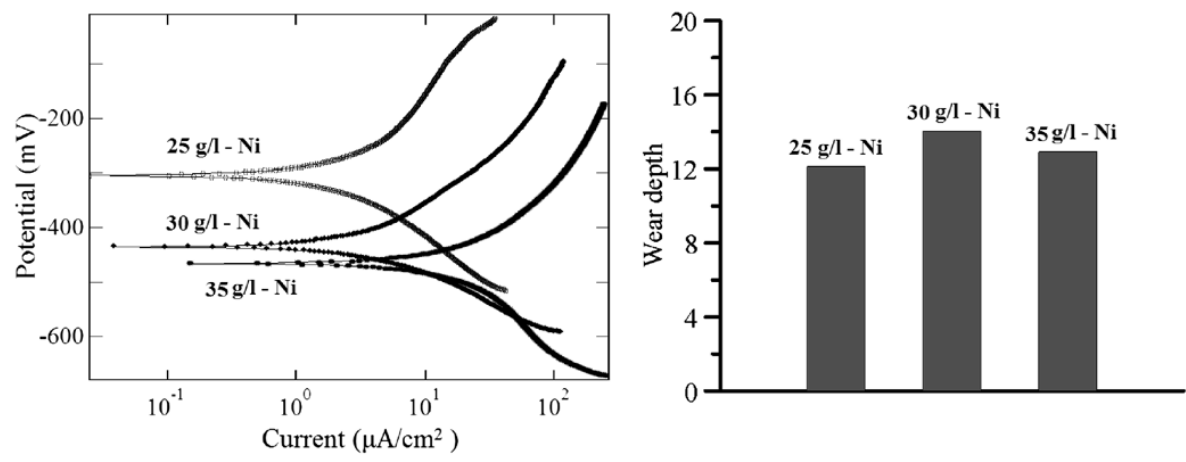

(c)

Figure 4 Tafel plots and variation of wear depths. For different compositions of $\mathrm{Ni}$ at different heat treatment temperatures (a) $300^{\circ} \mathrm{C}$, (b) $400^{\circ} \mathrm{C}$ and (c) $500^{\circ} \mathrm{C}$. 
composition of the coating in terms of the weight percentages of nickel, phosphorous and copper. Figure 5 shows the EDX spectra of the coated surface. From the analysis, it is found that the coating consists of $11 \% \mathrm{P}$, $4 \% \mathrm{Cu}$ and the remaining is Ni. Figure 6 shows the SEM of as-deposited and heat-treated $\left(300^{\circ} \mathrm{C}, 400^{\circ} \mathrm{C}, 500^{\circ} \mathrm{C}\right)$ $\mathrm{Ni}-\mathrm{P}$-Cu-coated surface. A deposit coarse nodular structure without any porosity in as-deposited condition is clear. Nodular deposition in a coating depends on nucleation rate and the growth of the deposit. Nucleation rate depends on the bath constituents and the operating condition of the experiment. From the figures, it is clear that due to heating, crack appears in the coating. Figure 7 shows the image of the worn surface and the corroded surface. The phase transformation behaviour has been studied by XRD. Figure 8 shows the XRD pattern of as-deposited and heat-treated condition. From the figure, it is clear that in as-deposited condition the coating is mostly amorphous, but crystalline peaks appear after heating. The major crystalline peaks of $\mathrm{Ni}$, $\mathrm{Cu}_{3} \mathrm{P}, \mathrm{Ni}_{3} \mathrm{P}$ and $\mathrm{Ni}_{3} \mathrm{P}_{2}$ appear after heating at $400^{\circ} \mathrm{C}$ for $1 \mathrm{~h}$.

\section{Analysis methodology and discussion \\ Grey relational coefficient}

In this study among the three responses, a higher value of corrosion potential $\left(E_{\text {corr }}\right)$ and a lower value of corrosion current density $\left(I_{\text {corr }}\right)$ are desired for good corrosion resistance and obviously a lower value of wear depth has been targeted. As there is a huge difference between the average value of each response, the result obtained from the analysis considering these values may not give the correct result when the effect of all the parameters are considered together. To eliminate this effect, the result data of each response have been normalized or scaled between 0 and 1 . The value 1 represents a good result and 0 represents a worse result. Here, $E_{\text {corr }}$ is normalized considering the bigger the better as a higher corrosion potential indicates good corrosion resistance. The $I_{\text {corr }}$ and wear depth both are normalized considering the smaller the better. Using this normalized value, the grey relational coefficients are calculated, which are explained stepwise:

Step 1: normalization Normalization of $E_{\mathrm{corr}}$ is performed using Equation 1:

$$
\text { Normalized value of } E_{\text {corr }}\left(E_{j}^{*}\right)=\frac{E_{j}-E_{\min }}{E_{\max }-E_{\min }}
$$

Normalization of $I_{\text {corr }}$ and wear depth is performed using Equations 2 and 3:

Normalized value of $I_{\text {corr }}\left(I_{j}^{*}\right)=\frac{I_{\max }-I_{j}}{I_{\max }-I_{\min }}$

Normalized value of $W\left(W_{j}^{*}\right)=\frac{W_{\max }-W_{j}}{W_{\max }-W_{\min }}$,

where $E_{j}=E_{\text {corr }}$ value corresponding to the $j$ th experiment $I_{j}=I_{\text {corr }}$ value corresponding to the $j$ th experiment

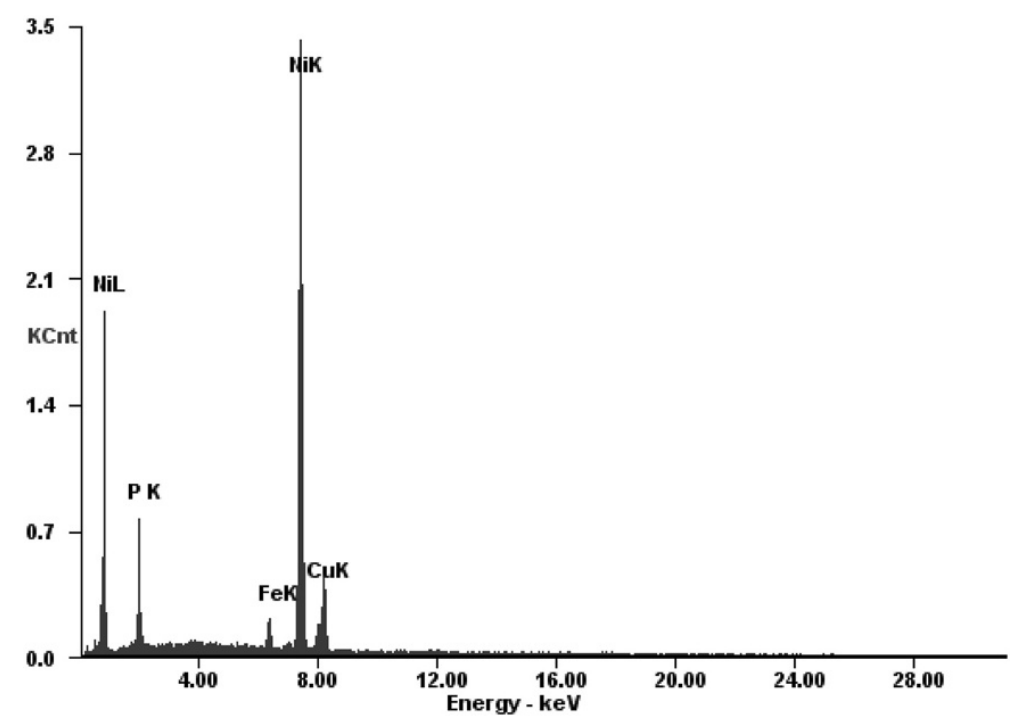

Figure 5 EDX spectra of Ni-P-Cu-coated surface. 
$W_{j}=$ wear value corresponding to the $j$ th experiment $j=$ sequence of experimental run $(j=1,2,3 \ldots)$; as there is a total of 27 experimental runs, the maximum value of $j$ is 27 .

Step 2: grey relational generation The grey relational coefficient $\left(g_{j}\right)$ for each response has been generated using Equation 4:

$$
g_{j}=\frac{\Delta R_{\min }^{*}+r \Delta R_{\max }^{*}}{\Delta R_{j}^{*}+r \Delta R_{\max }^{*}}
$$

where $R_{j}^{*}=$ the normalized response value $\left(E_{j}^{*}\right.$ for corrosion potential, $I_{j}^{*}$ for corrosion current and $W_{j}^{*}$ for wear depth)

$$
\Delta R_{j}^{*}=R_{j \max }^{*}-R_{j}^{*},
$$

$R_{j \max }^{*}=$ the maximum value of $R_{j}^{*}$

$\Delta R_{\max }^{*}$ and $\Delta R_{\min }^{*}$ are the maximum and minimum values of $\Delta R_{j}^{*}$, respectively.

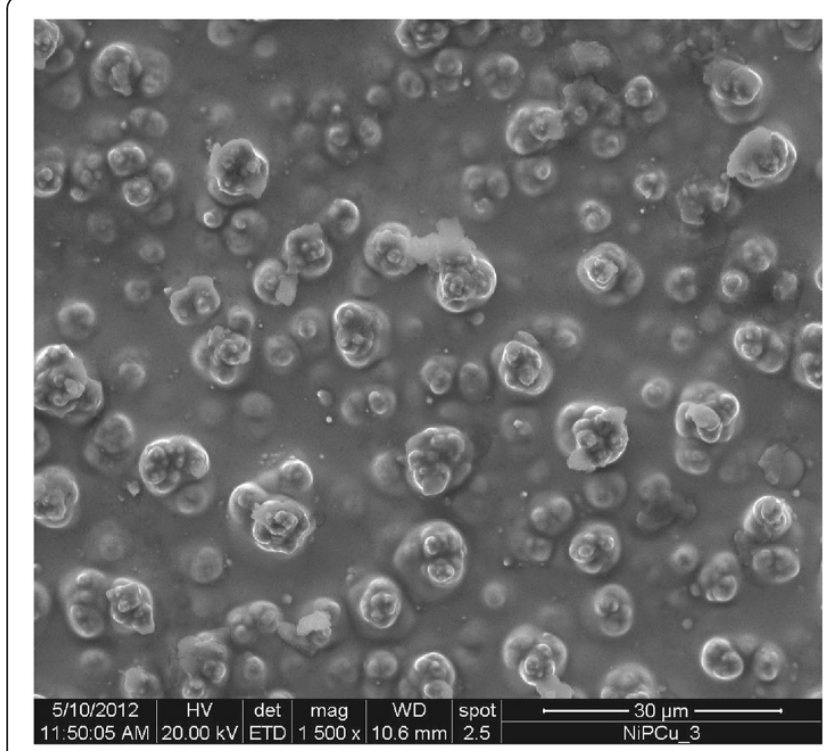

(a)

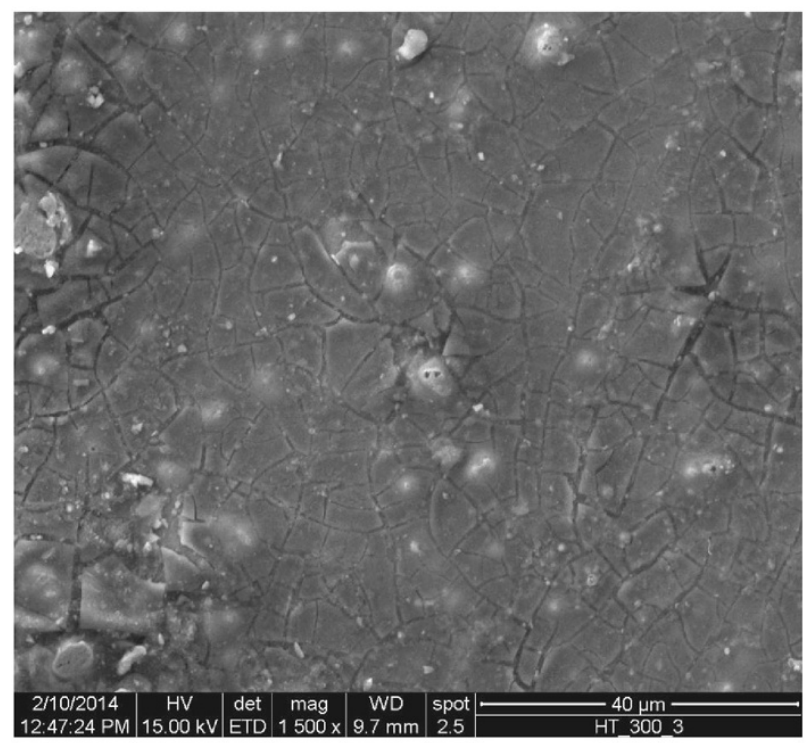

(b)

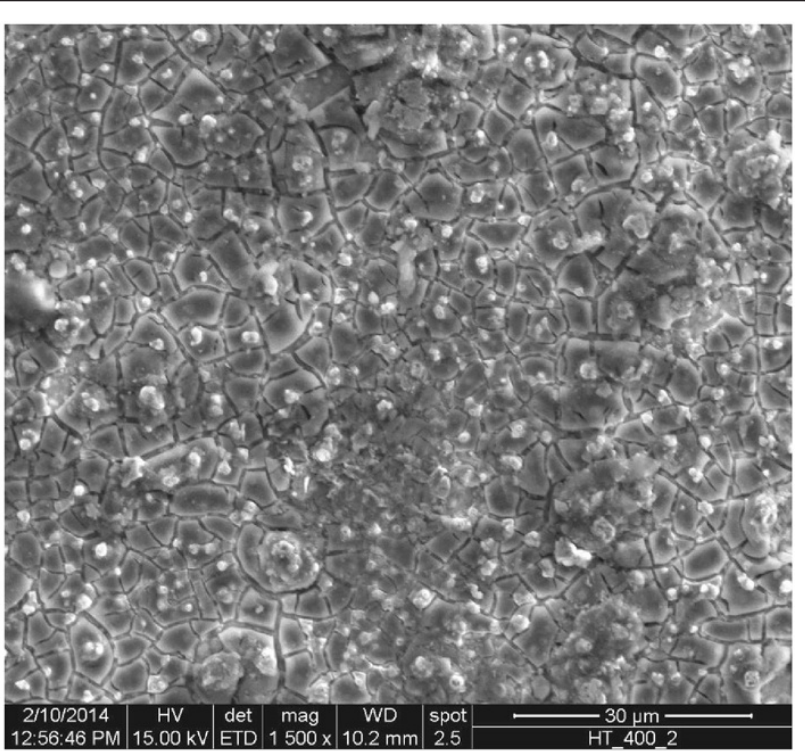

(c)

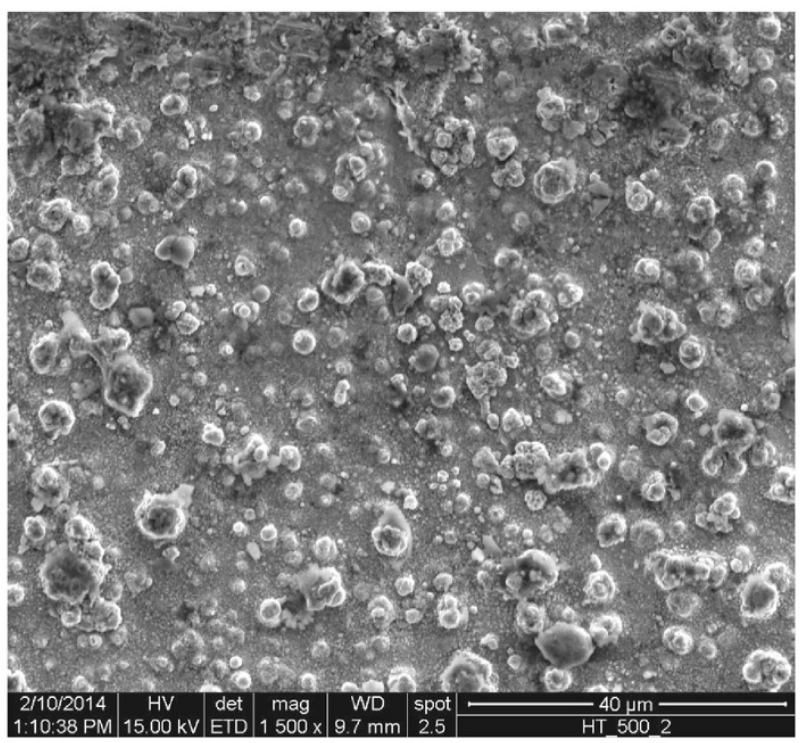

(d)

Figure 6 SEM images of Ni-P-Cu-coated surface. (a) As deposited, (b) heat treated at $300^{\circ} \mathrm{C}$, (c) heat treated at $400^{\circ} \mathrm{C}$ and (d) heat treated at $500^{\circ} \mathrm{C}$. 


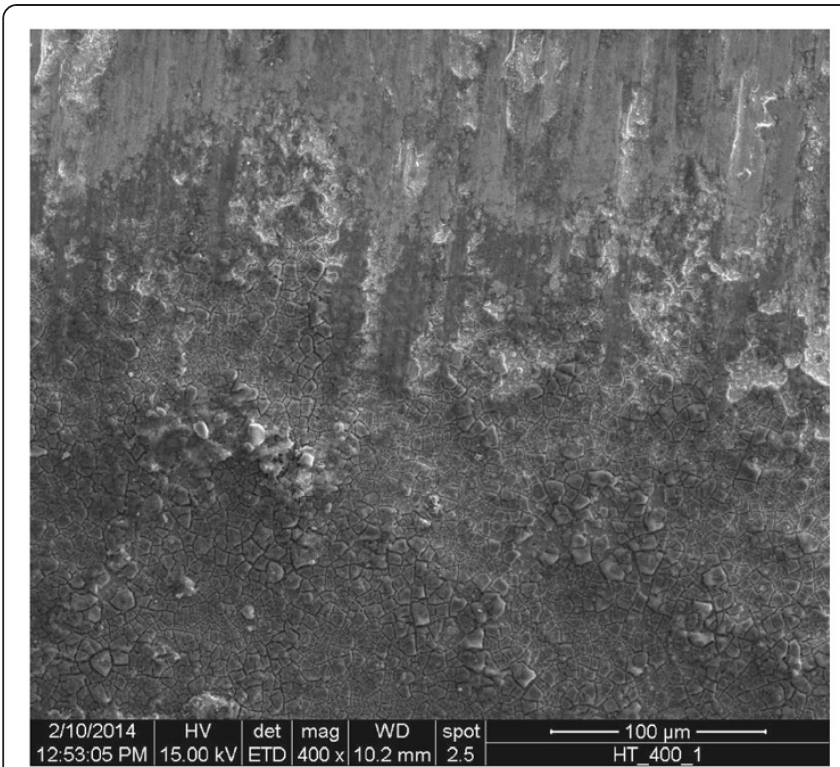

(a)

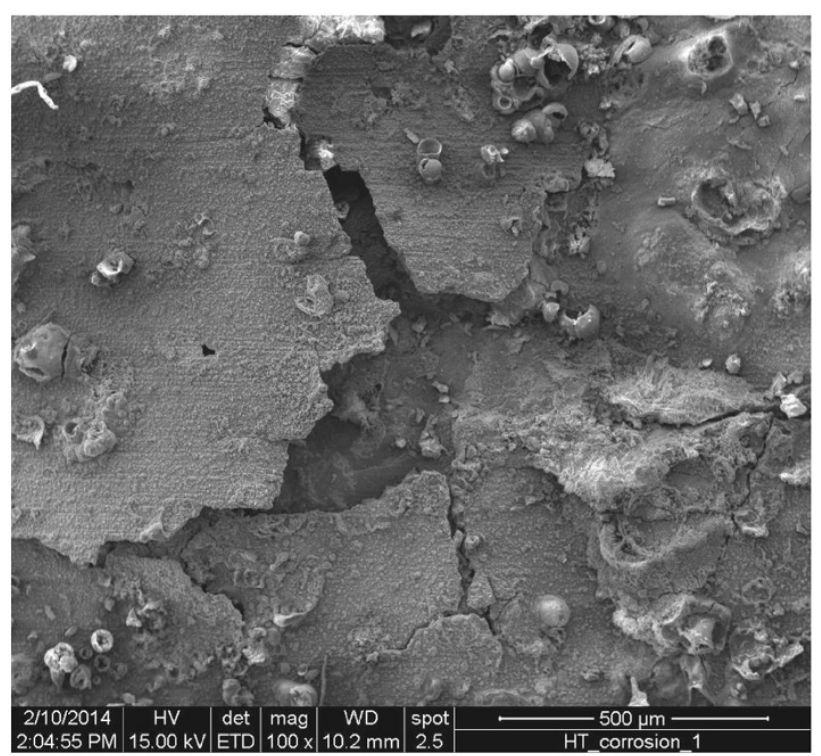

(b)

Figure 7 SEM images of the (a) worn surface and (b) corroded surface.

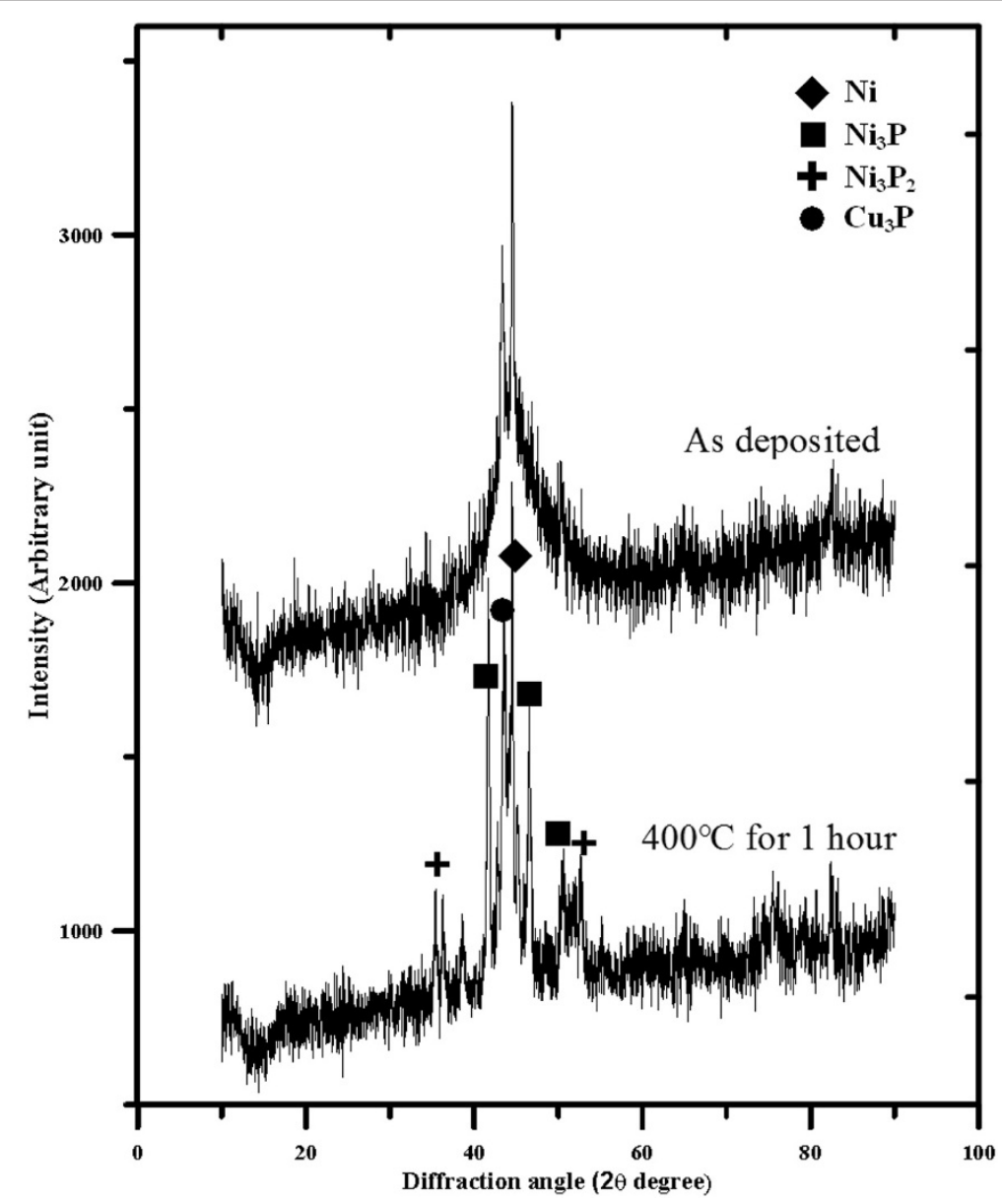

Figure 8 XRD pattern of Ni-P-Cu coating. 
Table 5 Results of grey analysis

\begin{tabular}{|c|c|c|c|c|c|c|c|c|c|}
\hline \multirow{2}{*}{$\begin{array}{l}\text { Experiment } \\
\text { number }\end{array}$} & \multicolumn{3}{|c|}{ Normalized value } & \multicolumn{3}{|l|}{$\Delta$ value } & \multicolumn{3}{|c|}{ Grey coefficient } \\
\hline & $E_{\text {corr }}$ & $I_{\text {corr }}$ & Wear & $E_{\text {corr }}$ & $I_{\text {corr }}$ & Wear & $E_{\text {corr }}$ & $I_{\text {corr }}$ & Wear \\
\hline 1 & 0.67010 & 0.99454 & 0.30323 & 0.32990 & 0.00546 & 0.69677 & 0.60248 & 0.98920 & 0.41779 \\
\hline 2 & 0.99532 & 0.93292 & 0.00000 & 0.00468 & 0.06708 & 1.00000 & 0.99074 & 0.88171 & 0.33333 \\
\hline 3 & 0.62719 & 0.53598 & 0.59771 & 0.37281 & 0.46402 & 0.40229 & 0.57286 & 0.51866 & 0.55415 \\
\hline 4 & 1.00000 & 1.00000 & 0.64136 & 0.00000 & 0.00000 & 0.35864 & 1.00000 & 1.00000 & 0.58231 \\
\hline 5 & 0.80205 & 0.94456 & 0.88526 & 0.19795 & 0.05544 & 0.11474 & 0.71639 & 0.90019 & 0.81335 \\
\hline 6 & 0.20197 & 0.12718 & 0.53929 & 0.79803 & 0.87282 & 0.46071 & 0.38520 & 0.36421 & 0.52045 \\
\hline 7 & 0.45186 & 0.90067 & 0.24496 & 0.54814 & 0.09933 & 0.75504 & 0.47703 & 0.83426 & 0.39839 \\
\hline 8 & 0.93331 & 0.94014 & 0.42239 & 0.06669 & 0.05986 & 0.57761 & 0.88231 & 0.89308 & 0.46399 \\
\hline 9 & 0.49731 & 0.88422 & 0.68487 & 0.50269 & 0.11578 & 0.31513 & 0.49866 & 0.81198 & 0.61340 \\
\hline 10 & 0.04797 & 0.82944 & 0.66924 & 0.95203 & 0.17056 & 0.33076 & 0.34434 & 0.74564 & 0.60186 \\
\hline 11 & 0.45059 & 0.91159 & 0.51475 & 0.54941 & 0.08841 & 0.48525 & 0.47646 & 0.84975 & 0.50748 \\
\hline 12 & 0.11779 & 0.56613 & 0.33784 & 0.88221 & 0.43387 & 0.66216 & 0.36174 & 0.53540 & 0.43023 \\
\hline 13 & 0.68993 & 0.75375 & 0.47323 & 0.31007 & 0.24625 & 0.52677 & 0.61723 & 0.67001 & 0.48696 \\
\hline 14 & 0.42794 & 0.92743 & 1.00000 & 0.57206 & 0.07257 & 0.00000 & 0.46639 & 0.87326 & 1.00000 \\
\hline 15 & 0.38749 & 0.48622 & 0.33873 & 0.61251 & 0.51378 & 0.66127 & 0.44943 & 0.49320 & 0.43056 \\
\hline 16 & 0.45297 & 0.98700 & 0.02652 & 0.54703 & 0.01300 & 0.97348 & 0.47754 & 0.97467 & 0.33933 \\
\hline 17 & 0.19838 & 0.74086 & 0.04850 & 0.80162 & 0.25914 & 0.95150 & 0.38414 & 0.65864 & 0.34447 \\
\hline 18 & 0.37908 & 0.49917 & 0.48712 & 0.62092 & 0.50083 & 0.51288 & 0.44606 & 0.49959 & 0.49364 \\
\hline 19 & 0.06869 & 0.49816 & 0.60544 & 0.93131 & 0.50184 & 0.39456 & 0.34933 & 0.49908 & 0.55893 \\
\hline 20 & 0.00000 & 0.62122 & 0.99743 & 1.00000 & 0.37878 & 0.00257 & 0.33333 & 0.56897 & 0.99490 \\
\hline 21 & 0.44486 & 0.17952 & 0.05149 & 0.55514 & 0.82048 & 0.94851 & 0.47387 & 0.37865 & 0.34518 \\
\hline 22 & 0.11404 & 0.61936 & 0.32570 & 0.88596 & 0.38064 & 0.67430 & 0.36076 & 0.56777 & 0.42579 \\
\hline 23 & 0.31534 & 0.00000 & 0.36487 & 0.68466 & 1.00000 & 0.63513 & 0.42206 & 0.33333 & 0.44048 \\
\hline 24 & 0.10409 & 0.93426 & 0.50457 & 0.89591 & 0.06574 & 0.49543 & 0.35819 & 0.88380 & 0.50229 \\
\hline 25 & 0.21224 & 0.47635 & 0.39813 & 0.78776 & 0.52365 & 0.60187 & 0.38827 & 0.48845 & 0.45377 \\
\hline 26 & 0.36468 & 0.19566 & 0.52374 & 0.63532 & 0.80434 & 0.47626 & 0.44040 & 0.38334 & 0.51216 \\
\hline 27 & 0.29855 & 0.77647 & 0.64940 & 0.70145 & 0.22353 & 0.35060 & 0.41617 & 0.69105 & 0.58782 \\
\hline
\end{tabular}

$r$ is a distinguishing coefficient, which belongs to [0, 1]. The distinguishing coefficient weakens the effect of $\max \Delta R_{\max }$ when it gets too big, enlarging the different significance of the relational coefficient. The suggested value of the distinguishing coefficient, $r$, is 0.5 , due to the moderate distinguishing effects and good stability of outcomes. Therefore, $r$ is adopted as 0.5 for further analysis in the present case.

The normalized values and grey relational coefficients of each response are shown in Table 5 . The

Table 6 Results obtained considering $E_{\text {corr }}$ and $I_{\text {corr }}$

\begin{tabular}{llll}
\hline $\begin{array}{l}\text { Principal } \\
\text { components }\end{array}$ & Eigenvalue & $\begin{array}{l}\text { Proportion of } \\
\text { overall variation }\end{array}$ & Eigenvector \\
\hline 1st & 1.5401 & 0.77 & {$[0.707,0.707]$} \\
2nd & 0.4599 & 0.23 & {$[0.707,-0.707]$} \\
\hline
\end{tabular}

conventional method for finding the grey relational grade is to take the average of these grey relational coefficients, i.e. considering equal contribution of each response to the overall variation. However, the eigenvalue of a principal component gives a fairly good idea about the variance of the original variables that can be explained by the principal component. A larger eigenvalue of a principal component implies that the

Table 7 Results obtained considering $E_{\text {corr }} I_{\text {corr }}$ and wear

\begin{tabular}{llll}
\hline $\begin{array}{l}\text { Principal } \\
\text { components }\end{array}$ & Eigenvalue & $\begin{array}{l}\text { Proportion of } \\
\text { overall variation }\end{array}$ & Eigenvector \\
\hline 1st & 1.5414 & 0.514 & {$[0.701,0.711,0.051]$} \\
2nd & 1.0358 & 0.345 & {$[0.21,-0.138,-0.968]$} \\
3rd & 0.4227 & 0.141 & {$[0.681,-0.689,0.246]$} \\
\hline
\end{tabular}


component's contribution in explaining the overall variation is higher. In this study, the corresponding weighting values are obtained from the principal component analysis.

\section{Weighted principal component analysis}

According to Antony (2000), the components with eigenvalues greater than 1 may be selected to replace the original responses. However, problems can arise in the situations where more than one eigenvalue becomes greater than 1 . The weighted principal component (WPC)based procedure ( $\mathrm{Su}$ and Tong 1997; Liao 2006) for optimization of multi-response processes makes use of all the principal components irrespective of the eigenvalues so that the overall variation in all the responses can be completely explained. In this approach, the proportion

Table 8 Results obtained considering $E_{\text {corr }}$ and $I_{\text {corr }}$

\begin{tabular}{|c|c|c|c|}
\hline \multirow{2}{*}{$\begin{array}{l}\text { Experiment } \\
\text { number }\end{array}$} & \multicolumn{2}{|c|}{ Principal component } & \multirow[t]{2}{*}{ MPI } \\
\hline & $\overline{P 1}$ & P2 & \\
\hline 1 & 1.12532 & -0.27341 & 0.80361 \\
\hline 2 & 1.32382 & 0.07708 & 1.03707 \\
\hline 3 & 0.77171 & 0.03832 & 0.60303 \\
\hline 4 & 1.41400 & 0.00000 & 1.08878 \\
\hline 5 & 1.14292 & -0.12995 & 0.85016 \\
\hline 6 & 0.52984 & 0.01484 & 0.41139 \\
\hline 7 & 0.92709 & -0.25256 & 0.65577 \\
\hline 8 & 1.25520 & -0.00761 & 0.96475 \\
\hline 9 & 0.92662 & -0.22152 & 0.66255 \\
\hline 10 & 0.77062 & -0.28372 & 0.52812 \\
\hline 11 & 0.93763 & -0.26391 & 0.66127 \\
\hline 12 & 0.63428 & -0.12278 & 0.46016 \\
\hline 13 & 0.91008 & -0.03731 & 0.69218 \\
\hline 14 & 0.94713 & -0.28765 & 0.66313 \\
\hline 15 & 0.66644 & -0.03094 & 0.50604 \\
\hline 16 & 1.02671 & -0.35147 & 0.70973 \\
\hline 17 & 0.73724 & -0.19408 & 0.52304 \\
\hline 18 & 0.66857 & -0.03784 & 0.50610 \\
\hline 19 & 0.59983 & -0.10588 & 0.43752 \\
\hline 20 & 0.63793 & -0.16659 & 0.45289 \\
\hline 21 & 0.60273 & 0.06732 & 0.47959 \\
\hline 22 & 0.65647 & -0.14636 & 0.47182 \\
\hline 23 & 0.53406 & 0.06273 & 0.42566 \\
\hline 24 & 0.87808 & -0.37160 & 0.59066 \\
\hline 25 & 0.61984 & -0.07082 & 0.46099 \\
\hline 26 & 0.58238 & 0.04035 & 0.45772 \\
\hline 27 & 0.78280 & -0.19435 & 0.55806 \\
\hline
\end{tabular}

Table 9 Results obtained considering $E_{\text {corr }} I_{\text {corr }}$ and wear

\begin{tabular}{|c|c|c|c|c|}
\hline \multirow{2}{*}{$\begin{array}{l}\text { Experiment } \\
\text { number }\end{array}$} & \multicolumn{3}{|c|}{ Principal components } & \multirow[t]{2}{*}{ MPI } \\
\hline & $\overline{P 1}$ & P2 & P3 & \\
\hline 1 & 1.14697 & -0.41441 & -0.16849 & 0.4228 \\
\hline 2 & 1.33841 & -0.23629 & 0.14919 & 0.62746 \\
\hline 3 & 0.79860 & -0.48769 & 0.16908 & 0.26607 \\
\hline 4 & 1.44170 & -0.49168 & 0.13525 & 0.5904 \\
\hline 5 & 1.18370 & -0.76110 & 0.06771 & 0.35539 \\
\hline 6 & 0.55552 & -0.47317 & 0.13941 & 0.14195 \\
\hline 7 & 0.94788 & -0.40060 & -0.15194 & 0.32758 \\
\hline 8 & 1.27714 & -0.38710 & 0.09966 & 0.53695 \\
\hline 9 & 0.95816 & -0.60110 & -0.06897 & 0.27539 \\
\hline 10 & 0.80223 & -0.61319 & -0.13119 & 0.18230 \\
\hline 11 & 0.96405 & -0.50845 & -0.13617 & 0.30090 \\
\hline 12 & 0.65619 & -0.41439 & -0.01671 & 0.19196 \\
\hline 13 & 0.93389 & -0.43422 & 0.07849 & 0.34128 \\
\hline 14 & 0.99883 & -0.99057 & -0.03806 & 0.1662 \\
\hline 15 & 0.68768 & -0.39047 & 0.07217 & 0.22893 \\
\hline 16 & 1.04505 & -0.36269 & -0.26287 & 0.37496 \\
\hline 17 & 0.75514 & -0.34367 & -0.10747 & 0.25442 \\
\hline 18 & 0.69307 & -0.45311 & 0.08099 & 0.21133 \\
\hline 19 & 0.62824 & -0.53656 & 0.03152 & 0.1422 \\
\hline 20 & 0.68894 & -0.97158 & 0.07973 & 0.03016 \\
\hline 21 & 0.61901 & -0.28688 & 0.14673 & 0.23989 \\
\hline 22 & 0.67829 & -0.41475 & -0.04077 & 0.19980 \\
\hline 23 & 0.55533 & -0.38375 & 0.16611 & 0.1764 \\
\hline 24 & 0.90509 & -0.53296 & -0.24144 & 0.24730 \\
\hline 25 & 0.64261 & -0.42512 & 0.03950 & 0.18920 \\
\hline 26 & 0.60740 & -0.45618 & 0.16179 & 0.17763 \\
\hline 27 & 0.81305 & -0.57698 & -0.04812 & 0.21206 \\
\hline
\end{tabular}

of overall variation explained by each component is treated as the weight to combine all the principal components in order to form a multi-response performance index (MPI). Then, the best combination of the parametric settings can easily be obtained which can optimize the MPI. The procedure for calculating MPI is described stepwise:

Table 10 Response table considering $E_{\text {corr }}$ and $I_{\text {corr }}$

\begin{tabular}{lllll}
\hline Parameters & \multicolumn{2}{l}{ Level } & & Deviation \\
\cline { 2 - 4 } & $\mathbf{1}$ & $\mathbf{2}$ & $\mathbf{3}$ & \\
\hline$A$ & 0.7863 & 0.5833 & 0.4817 & 0.3047 \\
$B$ & 0.607 & 0.6333 & 0.611 & 0.0263 \\
$C$ & 0.6498 & 0.6706 & 0.5308 & 0.1398 \\
$D$ & 0.6106 & 0.6346 & 0.606 & 0.0286 \\
\hline
\end{tabular}


Table 11 Response table considering $E_{\text {corr }} I_{\text {corr }}$ and wear

\begin{tabular}{lllll}
\hline Parameters & Level & & Deviation \\
\cline { 2 - 4 } & $\mathbf{1}$ & $\mathbf{2}$ & $\mathbf{3}$ & \\
\hline$A$ & 0.3938 & 0.2503 & 0.1794 & 0.2144 \\
$B$ & 0.2671 & 0.272 & 0.2844 & 0.0173 \\
$C$ & 0.3079 & 0.2917 & 0.2239 & 0.084 \\
$D$ & 0.253 & 0.3072 & 0.2633 & 0.0542 \\
\hline
\end{tabular}

Step 1: eigenvalue and eigenvectors and proportion of overall variance The eigenvalue $(\lambda)$ and eigenvectors $(V)$ are calculated from Equation 5 imposing a condition $\sum_{k=1}^{Q} V_{k}^{2}=1$

$$
[G-\lambda I] \times[V]=0
$$

where

$$
G=\left[\begin{array}{cccc}
\operatorname{var}(1) & \operatorname{cov}(1,2) & \ldots & \operatorname{cov}(1, k) \\
\operatorname{cov}(2,1) & \operatorname{var}(2) & \ldots & \operatorname{cov}(2, k) \\
\ldots & \ldots & \ldots & \ldots \\
\operatorname{cov}(j, 1) & \operatorname{cov}(R, 2) & \ldots & \operatorname{var}(R, k)
\end{array}\right]
$$

is the covariance matrix of grey relational coefficients.

$k$ is the number of quality characteristics; in this problem, the maximum value of $k$ is 3 .

The proportion of overall variance or weight is calculated using Equation 6:

$$
W_{k}=\frac{\lambda_{k}}{\sum_{k=1}^{Q} \lambda_{k}}
$$

The eigenvalues, eigenvectors and proportion of overall variance considering only corrosion parameters $\left(E_{\text {corr }}\right.$ and $\left.I_{\text {corr }}\right)$ are shown in Table 6, and the corresponding values considering both corrosion and wear $\left(E_{\text {corr }} I_{\text {corr }}\right.$ and $W$ ) are shown in Table 7 .
Step 2: calculation of principal components and MPI The principal components are calculated using Equation 7:

$$
[P]=[g] \times[V]
$$

The MPI is calculated using Equation 8:

$$
\mathrm{MPI}=\sum_{k=1}^{Q} P_{j, k} \times W_{k, 1}
$$

The principal components and MPI considering only corrosion parameters $\left(E_{\text {corr }}\right.$ and $\left.I_{\text {corr }}\right)$ are shown in Table 8 , and the corresponding values considering both corrosion and wear $\left(E_{\text {corr }}, I_{\text {corr }}\right.$ and $\left.W\right)$ are shown in Table 9.

\section{Optimum combination of parameters}

As the design of experiment is orthogonal, the effect of each parameter on MPI can be separated out by taking the average of same levels of each input parameter. For example, among the 27 experiments, there are 9 experiments, which include the level 1 of parameter $A$. Taking the average of these 9 MPI values, the mean MPI of level 1 for parameter $A$ can be calculated. Similar procedure is applicable for other parameters. Table 10 shows the mean response table of the MPI taking only corrosion parameters (corrosion potential and corrosion current density), and Table 11 shows the same considering all the three parameters (corrosion potential, corrosion current and wear depth). Figures 9 and 10 show the main effect plots obtained from the response tables, respectively. From the plots, the optimum combination of input parameters can be obtained. As the larger value of MPI corresponds better multiple response characteristics, the optimum combination can be obtained by selecting the largest level average of each parameter. Figure 9 yields the optimum combination considering only corrosion parameters is A1B2C2D2, and Figure 10 yields the optimum combination considering corrosion parameters and wear together is $\mathrm{A} 1 \mathrm{~B} 3 \mathrm{C} 1 \mathrm{D} 2$.

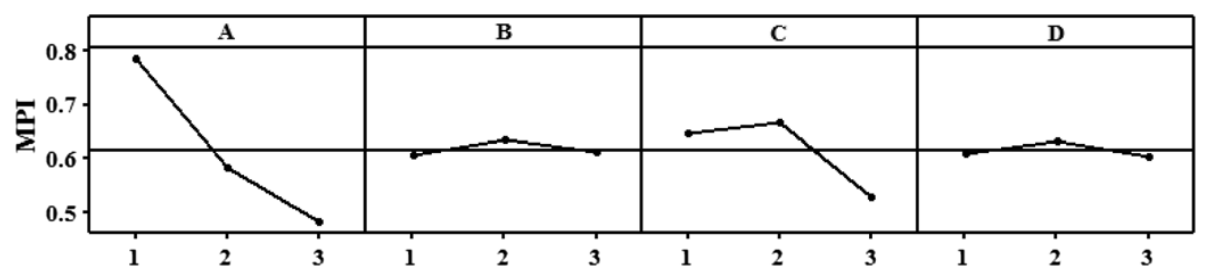

Figure 9 Main effect plot considering $E_{\text {corr }}$ and $I_{\text {corr }}$. 


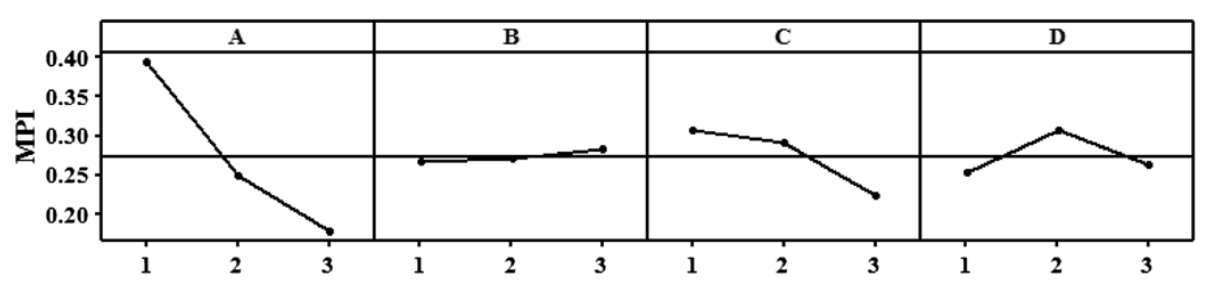

Figure 10 Main effect plot considering $E_{\text {corr }} I_{\text {corr }}$ and wear.

\section{Significance of parameters on MPI}

The response table also reveals the significance of each individual factor. In the response tables, the maximum deviation of each parameter is listed in the right column. It is obtained by subtracting the lowest mean MPI from the largest mean MPI value among the three levels of any parameter. The parameter has huge impact on the multiple responses, which has maximum deviation. From the tables, it is clear that parameter $A$, i.e. concentration of nickel sulphate, and parameter $C$, i.e. concentration of copper sulphate, have positive impact on the corrosion and wear property. The effect of nickel is highly dominant for both the cases, but the effect of copper is higher when only corrosion parameters are considered. It has been seen that due to heat treatment the structure of the coating transforms into crystalline. The coating becomes hard mainly due to the formation of the nickel phosphide structure at $400^{\circ} \mathrm{C}$, and thus, improved wear resistance is achieved at this stage along with the corrosion. According to Hui-Sheng et al. (2001), after heating $500^{\circ} \mathrm{C}$ for $1 \mathrm{~h}$, the metastable phase $\mathrm{Ni}_{5} \mathrm{P}_{2}$ transforms completely to stable $\mathrm{Ni}_{3} \mathrm{P}$ phase. It leads to harder and wear resistant coating due to crystallization which leads to more corrosive prone surface. Thus, $500^{\circ} \mathrm{C}$ may not be the optimum heat treatment temperature. Hence, this present analysis has a good agreement with this result. The results of analysis of variance (ANOVA) considering the corrosion parameters $\left(E_{\text {corr }}\right.$ and $\left.I_{\text {corr }}\right)$ and also considering the corrosion parameters and wear

Table 12 ANOVA table considering $E_{\text {corr }}$ and $I_{\text {corr }}$

\begin{tabular}{llllll}
\hline Source & $\boldsymbol{d} \boldsymbol{f}$ & SS & MS & $\boldsymbol{F}$ & $\boldsymbol{P}$ \\
\hline$A$ & 2 & 0.43318 & 0.21659 & 11.77 & 46.62 \\
$B$ & 2 & 0.00362 & 0.00181 & 0.1 & 0.39 \\
$C$ & 2 & 0.1024 & 0.0512 & 2.78 & 11.02 \\
$D$ & 2 & 0.00425 & 0.00213 & 0.12 & 0.46 \\
$A \times B$ & 4 & 0.01109 & 0.00277 & 0.15 & 1.19 \\
$A \times C$ & 4 & 0.20227 & 0.05057 & 2.75 & 21.77 \\
$B \times C$ & 4 & 0.06183 & 0.01546 & 0.84 & 6.65 \\
Error & 6 & 0.11043 & 0.01841 & & 11.89 \\
Total & 26 & 0.92908 & & & 100.00 \\
\hline
\end{tabular}

together are shown in Tables 12 and 13, respectively. The tables reveal that the percentage contribution of nickel is highest for both the conditions. Along with this the ANOVA results also focus on the significance of the interaction of parameters on the responses. It is clear from both the ANOVA tables that the percentage contribution of the interaction between nickel and copper is highest among the three interactions.

\section{Confirmation test}

To validate the result obtained from the analysis, a confirmation test was carried out with the optimum combination of parameters. Coatings are developed with the optimum combination of parameters obtained from optimization analysis, viz. A1B2C2D2 for corrosion optimization and A1B3C1D2 for combined corrosion and wear optimization. These coatings are then subjected to corrosion and wear tests. The results of these tests are compared with the tests on coatings developed with mid-level combination of parameters, i.e. $\mathrm{A} 2 \mathrm{~B} 2 \mathrm{C} 2 \mathrm{D} 2$. It is because with this combination the bath is most stable for a long time, and maximum thickness of coating can be achieved. However, the aim is to find out the best quality coating against corrosion and wear. Hence, a comparison between the mid-level result and the optimum level results has been carried out. The result of the confirmation test is tabulated in Table 14. From the table, it is clear that at optimum condition for corrosion, the value of corrosion potential is

Table 13 ANOVA table considering $E_{\text {corr }} I_{\text {corr }}$ and wear

\begin{tabular}{llllll}
\hline Source & $\boldsymbol{d} \boldsymbol{f}$ & SS & MS & $\boldsymbol{F}$ & $\boldsymbol{P}$ \\
\hline$A$ & 2 & 0.214715 & 0.107358 & 11.74 & 42.44 \\
$B$ & 2 & 0.001432 & 0.000716 & 0.08 & 0.28 \\
$C$ & 2 & 0.03575 & 0.017875 & 1.95 & 7.07 \\
$D$ & 2 & 0.014896 & 0.007448 & 0.81 & 2.94 \\
$A \times B$ & 4 & 0.021066 & 0.005266 & 0.58 & 4.16 \\
$A \times C$ & 4 & 0.122368 & 0.030592 & 3.34 & 24.19 \\
$B \times C$ & 4 & 0.040801 & 0.0102 & 1.12 & 8.06 \\
Error & 6 & 0.054888 & 0.009148 & & 10.85 \\
Total & 26 & 0.505917 & & & 100.00 \\
\hline
\end{tabular}


Table 14 Results of confirmation test

\begin{tabular}{|c|c|c|c|c|c|c|c|}
\hline & \multicolumn{4}{|c|}{ Parameters } & \multicolumn{2}{|c|}{$\begin{array}{l}\text { Polarization test } \\
\text { result }\end{array}$} & \multirow{2}{*}{$\begin{array}{l}\text { Wear } \\
\text { test } \\
\text { result } \\
(\mu \mathrm{m})\end{array}$} \\
\hline & $A(g / l)$ & $B(g / l)$ & $C(g / l)$ & $D\left({ }^{\circ} \mathrm{C}\right)$ & $\begin{array}{l}E_{\text {corr }}(\mathrm{mV} \\
\text { vs. SCE) }\end{array}$ & $\begin{array}{l}I_{\text {corr }}(\mu \mathrm{A} / \\
\left.\mathrm{cm}^{2}\right)\end{array}$ & \\
\hline $\begin{array}{l}\text { Mid-level } \\
\text { combination }\end{array}$ & 30 & 15 & 0.5 & 400 & -461.38 & 5.032 & 19.37 \\
\hline $\begin{array}{l}\text { Optimum } \\
\text { level for } \\
\text { corrosion }\end{array}$ & 25 & 10 & 0.5 & 400 & -233.31 & 0.790 & - \\
\hline $\begin{array}{l}\text { Optimum } \\
\text { level for } \\
\text { corrosion } \\
\text { and wear }\end{array}$ & 25 & 20 & 0.3 & 400 & -432.65 & 1.207 & 11.56 \\
\hline
\end{tabular}

improved by $49 \%$, while the value of corrosion current decreases by $84 \%$. For combined corrosion and wear optimization case, the value of corrosion potential is improved by $7 \%$, while the value of corrosion current decreases by $76 \%$ and wear depth decreases by $40 \%$. Thus, the optimum combination of parameters yields a better coating. The polarization curves for both the optimum conditions and mid-level combination are shown in Figure 11. The improvement of corrosion resistance of the coatings obtained from the optimum combination of parameters is clearly seen in these plots since corrosion potential increases and corrosion current decreases from the mid-level combination.

\section{Conclusions}

The electroless ternary Ni-P-Cu coating has been developed on mild steel substrate by varying four input design parameters, namely concentration of nickel source (nickel sulphate), concentration of reducing agent (sodium hypophosphite), concentration of copper source (copper sulphate) and post-deposition heat treatment temperature. The design of experiment was done by Taguchi $\mathrm{L}_{27} \mathrm{OA}$ with

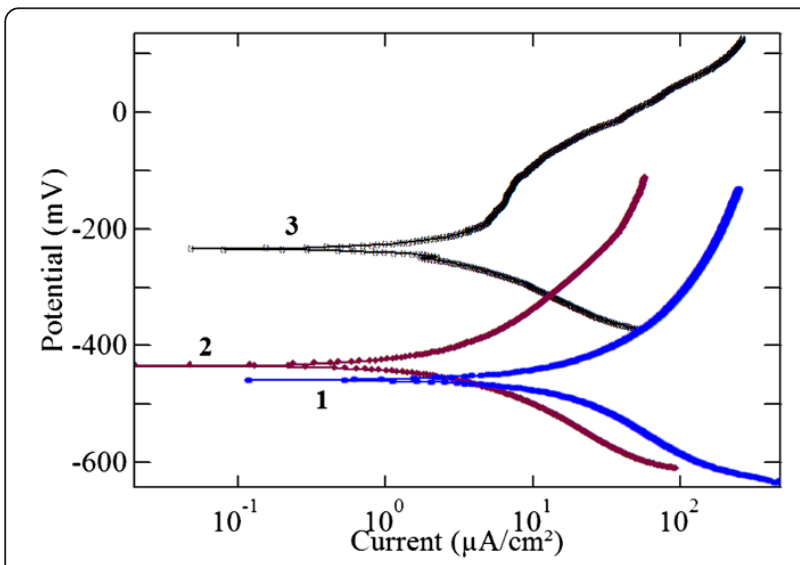

Figure 11 Tafel plots. Mid-level combination (1), optimum combination considering corrosion and wear together (2) and optimum combination considering only corrosion (3)
27 experimental runs. The wear depth of the heat-treated coatings was measured with a multi-tribotester instrument with block on roller configuration. The polarization (corrosion) tests were carried out using a potentiostat instrument. By extrapolating the Tafel plot, the corrosion current density and the corrosion potential were measured. Then, the grey analysis together with weighted principal component analysis is successfully employed for finding out the optimal combinations of the design process parameters of electroless Ni-P-Cu coatings for better value of polarization test and also considering the polarization and wear test together. Confirmation tests were carried out for both the cases to validate the experimental value. The energy dispersive X-ray analysis shows that it is a pure ternary coating consisting of nickel phosphorous and copper; the surface morphology and phase transformation behaviour have been studied by SEM and XRD analyses, respectively.

\section{Competing interests}

The authors declare that they have no competing interests.

\section{Authors' contributions}

SR carried out the experiments, analysed the data and drafted the manuscript. PS supervised the experiments, monitored the analysis and corrected the manuscript. Both authors read and approved the final manuscript.

Received: 23 May 2014 Accepted: 14 July 2014

Published online: 08 August 2014

\section{References}

Sahoo, P. \& Das, SK. (2011). Tribology of electroless nickel coatings - a review. Materials and Design, 32, 1760-1775.

Yu, H, Sun, X, Luo, SF, Wang, YR, \& Wu, ZQ. (2002). Multifractal spectra of atomic force microscope images of amorphous electroless Ni-P-Cu alloy. Applied Surface Science, 191, 123-127.

Aal, AA, \& Aly, MS. (2009). Electroless Ni-Cu-P plating onto open cell stainless steel foam. Applied Surface Science, 255, 6652-6655.

Palaniappa, M, \& Seshadri, SK. (2008). Friction and wear behaviour of electroless $\mathrm{Ni}-\mathrm{P}$ and Ni-W-P alloy coatings. Wear, 26, 735-740.

Balaraju, JN, Jahan, SM, \& Rajam, KS. (2006a). Studies on autocatalytic deposition of ternary Ni-W-P alloys using nickel sulphamate bath. Surface and Coatings Technology, 201, 507-512.

Balaraju, JN, Anandan, C, \& Rajam, KS. (2006b). Influence of codeposition of copper on the structure and morphology of electroless Ni-W-P alloys from sulphate- and chloride-based baths. Surface and Coatings Technology, 200, 3675-3681.

Roy, S, \& Sahoo, P. (2013). Tribological performance optimization of electroless Ni-P-W coating using weighted principal component analysis. Tribology in Industry, 35(4), 297-307.

Roy, S, \& Sahoo, P. (2012). Corrosion study of electroless Ni-P-W coatings using electrochemical impedance spectroscopy. Portugaliae Electrochimica Acta, 30(3), 203-220.

Abdel Aal, A, B. Hassan, H, \& Abdel Rahim, MA. (2008). Nanostructured Ni-P-TiO 2 composite coatings for electrocatalytic oxidation of small organic molecules. Journal of Electroanalytical Chemistry, 619-620, 17-25.

Chen, W, Gao, W, \& He, Y. (2010). A novel electroless plating of Ni-P-TiO, nano-composite coatings. Surface \& Coatings Technology, 204, 2493-2498.

Novakovic, J, \& Vassiliou, P. (2009). Vacuum thermal treated electroless $\mathrm{NiP}_{-} \mathrm{TiO}_{2}$ composite coatings. Electrochimica Acta, 54, 2499-2503.

Alirezaei, S, Monirvaghefi, SM, Salehi, M, \& Saatchi, A. (2007). Wear behavior of $\mathrm{Ni}-\mathrm{P}$ and $\mathrm{Ni}-\mathrm{P}-\mathrm{Al}_{2} \mathrm{O}_{3}$ electroless coatings. Wear, 262, 978-985.

Balaraju, JN, Kalavati, \& Rajam, KS. (2006c). Influence of particle size on the microstructure, hardness and corrosion resistance of electroless $\mathrm{Ni}-\mathrm{P}-\mathrm{Al}_{2} \mathrm{O}_{3}$ composite coatings. Surface \& Coatings Technology, 200, 3933-3941.

Ramalho, A, \& Miranda, JC. (2005). Friction and wear of electroless NiP and NiP + PTFE coatings. Wear, 259, 828-834. 
Huang, YS, Zeng, XT, Annergren, I \& Liu, FM. (2003). Development of electroless NiP-PTFE-SiC composite coating. Surface and Coatings Technology, 167, 207-211.

Lin, CJ, Chen, KC, \& He, JL. (2006). The cavitation erosion behavior of electroless Ni-P-SiC composite coating. Wear, 26, 1390-1396.

Jiagiang, G, Lei, L, Yating, W, Bin, S, \& Wenbin, H. (2006). Electroless Ni-P-SiC composite coatings with superfine particles. Surface \& Coatings Technology, 200, 5836-5842.

Liu, G, Yang, L, Wang, L, Wang, S, Chongyang, L, \& Wang, J. (2010). Corrosion behavior of electroless deposited Ni-Cu-P coating in flue gas condensate. Surface \& Coatings Technology, 204, 3382-3386.

Valova, E, Georgieva, J, Armyanov, S, Avramova, I, Dille, D, Kubova, O, \& Delplancke-Ogletree, M-P. (2010). Corrosion behavior of hybrid coatings: electroless Ni-Cu-P and sputtered TiN. Surface \& Coatings Technology, 204, 2775-2781.

Liu, Y, \& Zhao, Q. (2004). Study of electroless Ni-Cu-P coatings and their anti-corrosion properties. Applied Surface Science, 228(1-4), 57-62.

Wang, YW, Xiao, CG, \& Deng, ZG. (1992). Structure and corrosion resistance of electroless Ni-Cu-P. Plating and Surface Finishing, 79(3), 57.

Balaraju, JN, \& Rajam, KS. (2005). Electroless deposition of Ni-Cu-P, Ni-W-P and Ni-W-Cu-P alloys. Surface \& Coatings Technology, 195, 154-161.

Tarozaitë, R, \& Selskis, A. (2006). Electroless nickel plating with $\mathrm{Cu}^{2+}$ and dicarboxylic acids additives. Transactions of the Institute of Metal Finishing, 84(2), 105-112.

Chen, CH, Chen, BH, \& Hong, L. (2006). Role of $\mathrm{Cu}^{2+}$ as an additive in electroless nickel-phosphorus plating system: a stabilizer or a co-deposit? Chemistry of Materials, 18, 2959-2968.

Zhao, Q, Liu, Y, \& Abel, EW. (2004). Effect of Cu content in electroless Ni-Cu-P-PTFE composite coatings on their anti-corrosion properties. Materials Chemistry and Physics, 87, 332-335.

Armyanov, S, \& Georgieva, J. (2007). Electroless deposition and some properties of $\mathrm{Ni}-\mathrm{Cu}-\mathrm{P}$ and Ni-Sn-P coatings. Journal of Solid State Electrochemistry, 11, 869-876.

Chen, CJ, \& Lin, KL. (1999). The deposition and crystallization behaviors of electroless Ni-Cu-P deposits. Journal of The Electrochemical Society, 146, 137-140.

Hui-Sheng, Y, Shou-Fu, L, \& Yong-Rui, W. (2001). A comparative study on the crystallization behavior of electroless $\mathrm{Ni}-\mathrm{P}$ and $\mathrm{Ni}-\mathrm{Cu}-\mathrm{P}$ deposits. Surface and Coatings Technology, 148, 143-148.

Mallory, GO, \& Hadju, JB. (1991). Electroless Plating: Fundamentals and Applications. Orlando: AESF.

Cissé, M, Abouchane, M, Anik, T, Himm, K, Belakhmima Rida, A, Ebn Touhami, M, Touir, R, \& Amiar, A. (2010). Corrosion resistance of electroless Ni-Cu-P ternary alloy coatings in acidic and neutral corrosive mediums. International Journal of Corrosion, 246908, 9.

Tosun, N. (2006). Determination of optimum parameters for multi-performance characteristics in drilling by using grey relational analysis. International Journal of Advance Manufacturing Technology, 28, 450-455.

Deng, J. (1982). Control problems of grey systems. System \& Control Letters, 5, 288-294.

Tarng, YS, Juang, SC, \& Chang, CH. (2002). The use of grey-based Taguchi methods to determine submerged arc welding process parameters in hard facing. Journal of Materials Processing Technology, 128, 1-6.

Narender Singh, P, Raghukandan, K, \& Pai, BC. (2004). Optimization by grey relational analysis of EDM parameters on machining Al-10\% SiCp composites. Journal of Materials Processing Technology, 155-156, 1658-1661.

Antony, J. (2000). Multi-response optimization in industrial experiments using Taguchi's quality loss function and principal component analysis. Quality and Reliability Engineering International, 16, 3-8.

Lua, HS, Chang, CK, Hwang, NC, \& Chung, CT. (2009). Grey relational analysis coupled with principal component analysis for optimization design of the cutting parameters in high-speed end milling. Journal of Materials Processing Technology, 209, 3808-3817.

Hotelling, H. (1993). Analysis of a complex of statistical variables into principal components. Journal of Educational Psychology, 24, 417-441.

Su, CT, \& Tong, LI. (1997). Multi-response robust design by principal component analysis. Total Quality Management, 8, 409-416.

Liao, HC. (2006). Multi-response optimization using weighted principal component. International Journal of Advance Manufacturing Technology, 27, 720-725.

\section{doi:10.1186/s40712-014-0010-y}

Cite this article as: Roy and Sahoo: Parametric optimization of corrosion and wear of electroless Ni-P-Cu coating using grey relational coefficient coupled with weighted principal component analysis. International Journal of Mechanical and Materials Engineering 2014 1:10.

\section{Submit your manuscript to a SpringerOpen ${ }^{\odot}$ journal and benefit from:}

- Convenient online submission

- Rigorous peer review

- Immediate publication on acceptance

- Open access: articles freely available online

- High visibility within the field

- Retaining the copyright to your article

Submit your next manuscript at $\gg$ springeropen.com 